\title{
Evaluation of the Use of Information Systems Pharmacy Management Officer Pharmacy in RSU Royal Prima Medan Year 2020
}

\author{
Yurlina Zai ${ }^{1}$, Chrismis Novalinda Ginting ${ }^{2}$, Sri Wahyuni Nasution ${ }^{3}$, \\ Ermi Girsang ${ }^{4}$ \\ ${ }^{1}$ Postgraduate Students Department Magister of Public Health, Faculty of Medicines at University Prima \\ Indonesia \\ ${ }^{2,3,4}$ Postgraduate Lecturer Department Magister of Public Health, Faculty of Medicines at University Prima \\ Indonesia
}

Corresponding Author: Chrismis Novalinda Ginting [Email: chrismis@unprimdn.ac.id]

\begin{abstract}
Management information systems are urgently needed by hospital pharmacy installations to maintain the quality of the hospital, protect patient safety and support fast and precise decision making. The application of management information systems in the pharmaceutical installation of the Royal Prima Medan Hospital has been running. The pharmaceutical installation system that has been implemented is evaluating, repairing and improving to keep up with the times.

The purpose of this study was to determine the effect of system quality, information quality, service quality on the use of pharmaceutical management information systems at Royal Prima Medan Hospital and the relationship between significant variables. This type of research is a mixed method with a sequential explanatory research strategy. This study uses the DeLone and Mclean information system success model. The research was conducted at the Royal Prima Medan Hospital with the research subjects being pharmaceutical officers at the Royal Prima Medan Hospital.

Data analysis was performed by multiple linear regression analysis. The numbers of respondents used in this study were 30 respondents with the characteristics of all respondents being female $(100 \%)$ and aged $25-29$ years $(43.33 \%)$. Based on the results of the T test, it can be concluded that system quality, information quality and service quality have no effect on system use. Simultaneously, system quality, information
\end{abstract}

quality and service quality do not have a significant effect on the use of management information systems simultaneously.

Keywords: Evaluation, Pharmaceutical Information Management System, D \& M is Success Model, Royal Prima Medan Hospital

\section{INTRODUCTION}

Advances in information technology in the application in the field of health has a huge impact so that it becomes your needs and demands that must be met to support public services, especially hospital which is one of the health care facilities and has a strategic role in the efforts to accelerate the improvement of the health of the people of Indonesia. Along with the progress of technology, the use of information technology in the health care system gives hope of improving the quality of health services with the help of Hospital Management Information System will provide tremendous benefits for all the components in a hospital, patients, doctors, nurses, management, partners hospital until with stakeholders (Odelia, 2018).

The implementation of Hospital Management Information System is very important to integrate all the information that is produced in the process of good service to help ease the administrative burden on hospitals, starting from the 
process of patient care in medical records, and financial assets. With Hospital Management Information System can streamline the process of implementation of the recording, calculation and reporting (Ratnasari, 2018).

Pharmacy services hospital is an activity in the hospital to support quality health services. It is clarified in the decree of the Minister of Health No. 1333/Menkes/ SK/XII/1999 about the standard of health service hospital mention of pharmacy services hospital is an integral part of the health care system hospital oriented to patient care, the provision of drug quality, including pharmacy services clinic that is affordable for all walks of life (Moh, 2016). The success of the system development is an investment to improve the quality of service to patients. Hospitals are required to provide the service with fast, appropriate and quality. In order to meet the demands of the service it support management information system is indispensable (Advistasari, 2015).

According to Larasati (2013) in the journal "Relations Factors Human, Organization and Technology (HOT-FIT Model) with the Performance of the Management Information System, Pharmacy Bhakti Wira Thamtama Semarang" (Sholistiyawati A., 2020), management information Systems pharmacy is an application of information systems can support the information required by the user in the service of the pharmaceutical-oriented patient care, the provision of drug quality, including pharmacy services clinic that is affordable for all public statements. With the information system management pharmacy then the distribution of the drug can be managed well so it is easy to get drugs in accordance with a doctor's prescription which will then be given to the patient.

To support pharmacy services, we need a management information system as a tool to achieve quality health services. Management information system pharmacy can manage the distribution of the drug in a more better so it is more easily obtained, and then given to the patient according to the doctor's prescription, so be aware of drug stock which is in accordance with the needs of the patient. Management information system pharmacy can be used to support the decision-making process for example in the procurement of the stock of the drug which is run with the help of computer devices (Murnita R. 2016).

As a supporter of that support quality of service in hospitals, this information system must support in order as a function of management. As already described by Sholistiyawati A.,et al (2020) that with the information system management pharmacy then the distribution of the drug can be managed well so it is easy to get drugs in accordance with a doctor's prescription which will then be given to the patient. It is expected that there management pharmacy, the aim of the hospital in improving health care and patient safety can be achieved.

The purpose of the evaluation of information systems pharmacy management in General Hospital the Royal Prima Medan is to measure, assess, improve or enhance information systems pharmacy management in order to find potential problems that are being faced. The results of the evaluation can be used as a reference to fix or improve information systems management pharmaceutical as well as develop the potential is still there, so it can be beneficial to the General Hospital Royal Prima Medan in improving the performance in the service of the hospital towards the better. Refers to research conducted by the Advistasari, Lutfan and Pudjaningsih (2015), that system Quality, information quality and service quality simultaneously have a positive influence on the use of the system in Regional General Hospital Of The City Of Semarang. Service quality has a significant influence whereas system quality and information quality have influence did not significantly affect the use of the system. System quality, information quality and service quality simultaneously have a 
positive influence on user satisfaction in General Hospital in the City of Semarang. System quality has a significant influence on user satisfaction, while information quality and service quality has an influence is not significant to the satisfaction of the user.

\section{LITERATURE REVIEW System Information}

Information system is a combination of activity data input, process and output information (Karim A., 2017). The information contained in the information system is one of the valuable asset for an organization because it is one of the strategic resources in improving the value of the business. (M. P. Mokodompit, 2017).

\section{Management}

Management is a series of activities to carry out the work through the functions of planning, organizing, directing and monitoring in order to achieve organizational goals effectively and efficiency. Therefore, it can be concluded that management is a process to manage human resources and other resources by planning, organizing, directing and monitoring to achieve the purpose. (Abdullah, 2014).

\section{Hospital Management Information System}

Hospital Management Information system is a set or activities and procedures that are organized and related to each other as well as the interdependence and designed in accordance with the plan in the effort to present information that is accurate, timely and according to the needs to support the process management functions and decision-making in providing health services in the Hospital. (Saputra E., Misfariyan. 2014).

\section{Management Information System Pharmacy}

The installation of the Hospital pharmacy is a part in the hospital that organizes all the activities of the pharmacy for the purposes of the hospital itself. The responsibility of the Pharmacy Installation also includes the use of effective drugs on the hospital concerned thoroughly (Qiyaam, Furqoni, \& Hariati, 2016). Management information system pharmacy can manage the distribution of the drug in a better so it is more easily obtained, and then given to the patient according to the doctor's prescription, so be aware of drug stock which is in accordance with the needs of the patient.

\section{Quality System}

Quality system means the quality of a combination of hardware and software in information systems. The quality of the system is a characteristic of information that is inherent for the system itself that can be in the form of ease of use, the reliability of the system itself, sophistication and time to respond.

\section{Quality Of Information}

The quality of the information is the output that is produced by the information systems used. the quality of the information can be in the form of the output of the information is easy to understand, accuracy, completeness, and the right time.

\section{Quality Of Service}

Quality of service becomes more important than the application of the other, because the user-users of the system now is more as customers and not the employees or users internal to the organization.

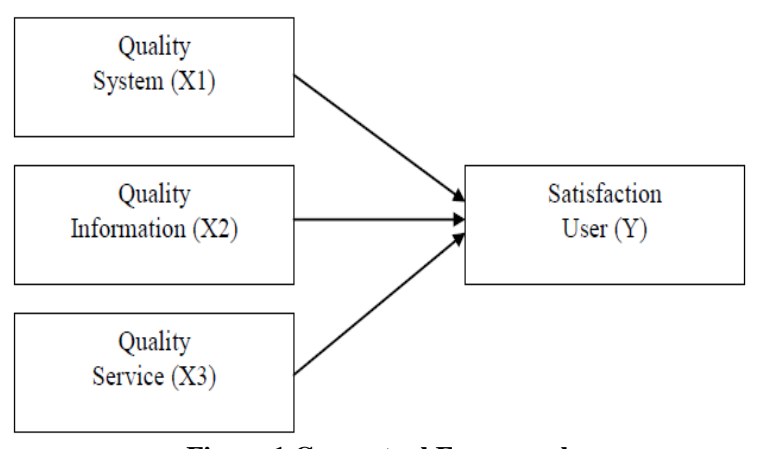

Figure 1 Conceptual Framework 


\section{Hypothesis}

Ha :

- The quality of the system (system quality) effect and significant impact on the use (use);

- Quality of information (information system) influential and significant impact on the use of the system (use);

- Quality of service (service quality) effect and significant impact on the use of the system (use);

Ho :

- The quality of the system (system quality) has no effect and significant impact on the use (use);

- Quality of information (information system) has no effect and significant impact on the use of the system (use);

- Quality of service (service quality) has no effect and significant impact on the use of the system (use);

\section{MATERIAL AND METHODS}

The type of research used is the method of combined (mixed methods) between quantitative and qualitative research methods. The strategy used in the method of this research is explanatory sequential, where the order of the quantitative and qualitative analysis, which aims to identify the components of the concept (sub-concepts) through the analysis of quantitative data and then collecting qualitative data in order to expand the information available. Mixed method resulted in the fact that more comprehensive in researching the problem of the research, because this research has the freedom to use all the means of collecting the required data. While the quantitative or qualitative only limited on the type of data collection tool specific course. (Budil S. Y., 2016). Research conducted at the General Hospital Royal Prima Medan, North Sumatra. The selection of this hospital due to the location of the hospital which is located in the middle of the city and belongs to one of the hospitals that stout known. The time this Research began to be carried out since the filing of the title in August 2020 until completed.

The population in this study consists of all the people who work in pharmacy installation in the General Hospital Royal. Employees who work in pharmacy installation is amounted to 32 people. Sample is a procedure of data collection where only a portion of the population that is taken and used to determine the properties and characteristics desired of a population (Siregar, 2013). The sampling technique used is the technique of sampling is nonprobability that the sampling technique is found or determined by the researcher. So that the sample is all of the people who work in pharmacy and is a user of information systems management in pharmacy installation. Of the 32 people who work in pharmacy installation, as many as 30 people who use Information Systems Pharmacy Management.

Source of research data, namely Primary Data and Secondary Data. Primary Data is the source of the research data obtained from the source directly to answer questions in research. According to Sujarweni (2014), the data obtained by interview and questionnaire by the speaker. Secondary Data is the source obtained from the records, books, magazines, and other sources that do not need to be processed again. This study uses data from books, journals, the internet, the research that has been done before, and document management General Hospital Royal Prima Medan.

\section{RESULTS}

\section{Characteristics of Respondents}

Based on the research that has been done, the researchers get the characteristics of the respondents as follows:

\section{By Gender}

Table 1 Description of Respondents' Characteristics by Gender

\begin{tabular}{|c|c|c|}
\hline Gender & Number of Respondents & Percentage (\%) \\
\hline Woman & 30 people & $100 \%$ \\
\hline Total & 30 people & $100 \%$ \\
\hline
\end{tabular}


From Table 1, based on gender, the numbers of respondents in this study were 30 women $(100 \%)$. This shows that the pharmacy installation staffs of the Royal Prima Hospital Medan are all women.

\section{By Age}

Table 2 Description of Respondents Characteristics by Age

\begin{tabular}{|c|c|c|}
\hline Age & Number of Respondents & Percentage (\%) \\
\hline $20-24$ years & 11 people & $36,6 \%$ \\
\hline $25-29$ years & 13 people & $43,3 \%$ \\
\hline $30-34$ years & 6 people & $20 \%$ \\
\hline Total & 30 people & $100 \%$ \\
\hline
\end{tabular}

From Table 2, Based on age, respondents aged 20-24 years were 11 people $(36.66 \%)$, aged $25-29$ years were 13 people $(43.33 \%)$ and aged $30-34$ years were 6 people $(20 \%)$.

\section{Effect of System Quality on the Use of Pharmacy Management Information Systems}

Based on the research that has been done, the following results are obtained:
From the table it can be seen that the system quality variable has no significant effect on the use of the system, this can be seen from the significance level (0.062) $<0.05$. Because the value of tcount is 1,949 , the system quality variable has no significant effect on usage.

Table 3. System Quality Test Results with the Use of

\begin{tabular}{|c|c|c|c|c|c|}
\hline \multirow{2}{*}{ Model } & \multicolumn{2}{|c|}{ Unstandardized Coefficients } & Standardized Coefficients & \multirow{2}{*}{$\boldsymbol{T}$} & \multirow{2}{*}{ Sig } \\
\cline { 2 - 6 } & $\boldsymbol{B}$ & Std. Error & Beta &, 416 &, 681 \\
\hline (Constant) &, 995 & 2,393 & & 1,949 &, 062 \\
\hline System quality &, 273 &, 140 &, 349 & 1,949 \\
\hline
\end{tabular}

4. The Effect of Information Quality on the Use of Pharmacy Management Information Systems

Based on the research that has been done, the following results are obtained:

Table 4. Information System Test Results with the Use of

\begin{tabular}{|l|c|c|c|c|c|}
\hline \multirow{2}{*}{ Model } & \multicolumn{2}{|c|}{ Unstandardized Coefficients } & Standardized Coefficients & \multirow{2}{*}{ T } & \multirow{2}{*}{ Sig } \\
\cline { 2 - 5 } & $B$ & Std. Error & Beta &, 416 &, 681 \\
\hline (Constant) &, 995 & 2,393 & &, 157 &, 877 \\
\hline Stress &, 22 &, 138 &, 029 &, 19 \\
\hline
\end{tabular}

The value of ttable $=(\alpha / 2 ; n-k-1)=$ $(0.05 / 2 ; 30-3-1)=(0.025 ; 26)=2.05552$. $\mathrm{HO}$ is rejected and $\mathrm{Ha}$ is accepted if tcount ttable. $\mathrm{HO}$ is accepted and $\mathrm{Ha}$ is rejected if tcount $<$ ttable. From the results of table, $\mathrm{Ha}$ is rejected because tcount $<$ ttable. From the table, it can be seen that the information quality variable has no significant effect on the use, this can be seen from the significance level $(0.877)>0.05$.

\section{The Effect of Service Quality on the Use of Pharmacy Management Information Systems}

Based on the research that has been done, the following results are obtained:

Table 5. Results of Service Quality with the Use of

\begin{tabular}{|c|c|c|c|c|c|}
\hline \multirow{2}{*}{ Model } & \multicolumn{2}{|c|}{ Unstandardized Coefficients } & \multirow{2}{*}{$\begin{array}{c}\text { Standardized Coefficients } \\
\text { Beta }\end{array}$} & \multirow{2}{*}{$T$} & \multirow{2}{*}{ Sig } \\
\hline & $\boldsymbol{B}$ & Std. Error & & & \\
\hline (Constant) & ,995 & 2,393 & & ,416 & ,681 \\
\hline Service quality & 242 &, 178 & 250 & 1,359 &, 186 \\
\hline
\end{tabular}

From the table, it can be seen that the service quality variable has no significant effect on usage, this can be seen from the significance level $(0.186)>0.05$. Because the tcount is 1.359 , the sleep pattern variable partially has no effect on usage.

\section{Relationship Between Significant Variables}

Based on the research that has been done the results of the relationship between significant variables, the following results are obtained: 


\begin{tabular}{|l|c|}
\hline \multicolumn{1}{|c|}{ Model } & Sig. \\
\hline (Constant) &, 681 \\
\hline System Quality => Usage &, 062 \\
\hline Information Quality => Usage &, 877 \\
\hline Service Quality => Usage &, 186 \\
\hline
\end{tabular}

\section{DISCUSSION}

\section{Characteristics Of Respondents}

Results characteristics of

respondents based on age are seen that the respondents are dominated by the age group of 26-35 years, and be at least the age group of $<26$ years. According to the Moh (2009), the age group of 26-35 years is the productive age of man in the work, where the function of the human body are working in optimal including memory, so that the General Hospital Royal Prima a lot of hiring employees with this age range. While the age groups of less than 26 years old is the age group of late adolescence. At the age of adolescence is also still in the productive age in the work. Respondents based on gender are all of the female gender, amounting to 30 people $(100 \%)$.

\section{The Influence Of The Quality Of The System Against The Use Of Management Information System Pharmacy}

Based on the results of the questionnaire that has been done, the Researchers argue that the quality of the information from the management information system pharmacy in General Hospital Royal Prima do not particularly affect the use of information systems pharmacy management because there are many pharmacists who have yet to understand about the quality of the system of management information systems pharmacy and also the quality of the system does not affect how many officers use the information system management as they have to use it to finish the job pharmacy.

This result is in accordance with the research of wu and wang in the journal Rahayu, et al (2018) entitled "Analysis of the Success of the Student affairs Information System with the Approach of the DeLone and McLean Model" which explains that the quality system is vital but not be something which is important when used. And also research the past (Radityo \& Zulaikha, 2007; Fatania, 2011; Tammubua et al., 2015) where the quality of the system do not affect the use of the information system because most of the respondents are less so understand the quality of the resulting system.

As for supporting the quality system in order to further improve the use is the dissemination of knowledge about the quality of the system and increase the level of trust the user so that the increase enthusiastic users which can be seen from how often users use the system. (Nurhaida M. A., 2019).

\section{The Influence of The Quality Of Information On The Use Of Management Information Systems Pharmacy}

Based on the results of the questionnaire that has been done, the researchers argue that the quality of the information from the management information system pharmacy in General Hospital Royal Prima do not particularly affect the use of information systems pharmacy management officer pharmacy. That the more good information system does not affect the use of the officers on information systems management pharmacy because the pharmacy should still do its job, so it should be using the information management system pharmacy.

This result is in accordance with the research of McGill et al. and Iivari which states that the quality of information does not have a significant influence on the use. The presentation of information that is less interesting, the relevance of the information less precise, and the language which is not easily understood is the lack of quality of the information produced. (F S Rahayu, 2018).

Although it has a negative value including daily used time remains to be further enhanced the use of users in the information system so that in the criteria of success are very high to remain stable. In the evaluation that has been done variable to use in the criteria of success is Very High. 


\section{The Influence Of Service Quality On The Use Of Information Systems Pharmacy Management}

Based on the results of the questionnaire that has been done, the researchers argue that the quality of service management information system pharmacy in General Hospital Royal Prima do not particularly affect the use of management information system pharmacy. That the quality of the services the system is still not well perceived by the user, the user system is still not received support from the service provider in the implementation of such a system in pharmacy installation, this is what finally made the users of the system are not interested in using information systems pharmacy management in a sustainable manner.

In terms of service, less response, make the lack of interest of the user to use the system to manage the data. Quality service diberikanseperti the best to use, the service response time and form an appropriate response. (Rahayu F. S., 2018).

According to Akhiroh (2008), service quality can be defined as something that is associated with the fulfillment of the needs of the user, the service can be said if the quality can provide the products and services in accordance with the needs and wishes of the user. Quality of service management information system focuses on the overall support received by the service provider system or technology (Musrifah, 2017).

\section{The Relationship Between The Variables Is Significant}

Based on the results of the questionnaire that has been done, the researchers argue that the quality of service the quality of the system, information quality and service quality of information systems pharmacy management in General Hospital the Royal Prima Medan no significant effect on the use of the system. Can view from the significant value of count is below the 0.05 significant.

\section{CONCLUSIONS AND RECOMMENDATIONS Conclusion}

1. The characteristics of the respondents of this research are $100 \%$ female and aged 20-24 years as many as 11 people (36.6\%), 25-29 years as many as 13 people $(43,3 \%)$ and $30-34$ years as many as 6 people $(20 \%)$.

2. The quality system has no influence on the use of information systems pharmacy management in General Hospital the Royal Prima Medan.

3. The quality system has no influence on the use of information systems pharmacy management in General Hospital the Royal Prima Medan.

4. The quality system has no influence on the use of information systems pharmacy management in General Hospital the Royal Prima Medan.

5. The results of the relationship of the variables significant of this research is the quality of the system, information quality and service quality of information systems management pharmaceutical no significant effect on the use of information systems pharmacy management in General Hospital the Royal Prima Medan

\section{Recommendations}

Need to do more research regarding the evaluation of hospital management information system in the General Hospital Royal Prima Medan overall. More research to know the cause of the hypothesis is rejected.

\section{Acknowledgement: None}

Conflict of Interest: None

\section{Source of Funding: None}

\section{REFERENCES}

1. Yulianti E.,dkk. 2015. Perancangan Sistem Informasi Manajemen Rumah Sakit Modul 
Farmasi. Lontar computer, Vol. 06, No.0 2. Universitas Udayana.

2. Murnita R.,dkk. 2016. Evaluation of the Performance of Pharmacy Management Information System At Roemani Muhammadiyah Hospital with HOT Fit Model. Jurnal Manajemen Kesehatan Indonesia, Vol. 04, No. 01. Universitas Diponegoro.

3. Sholistiyawati A.,dkk. 2019. Hubungan Faktor Human, Organization dan technology (Hot-fit model) dengan Kinerja Sistem Informasi Manajemen Farmasi di Rumah Sakit Bhakti Wira Thamtama Semarang. E-Journal, Vol. 08, No. 02. Universitas Diponegoro.

4. Odelia, Evi Maya. 2018. Pengembangan Kapasitas Organisasi Melalui Penerapan Sistem Informasi Manajemen Rumah sakit (SIMRS) Untuk Meningkatkan Mutu Pelayanan Kesehatan Di RSUD Dr. Mohamad Soewandhie Surabaya. Fakultas Ilmu Sosial Dan Ilmu Politik Universitas Airlangga Surabaya.

5. Ratnasari, Fitriani. 2018. Evaluasi Sistem Informasi Manajemen Rumah Sakit (SIMRS) Dengan Metode HOT- FIT Di Rumah Sakit Umum Daerah (RSUD) Undata Provinsi Sulawesi Tengah. Fakultas Kesehatan Masyarakat Universitas Tadulako Sulawesi Tengah.

6. Kemenkes RI., 2016, Tentang Standar Pelayanan Farmasi di Rumah Sakit, Keputusan Menteri Kesehatan Republik Indonesia No. 72 Tahun 2016, Direktorat Jendral Pelayanan Kefarmasian dan Alat Kesehatan, Jakarta.

7. Advistasari Y. D.,dkk. 2015. Evaluasi Siatem Informasi Manajemen Farmasi Menggunakan D\&M is Success Model untuk Mendukung Pengelolaan Obat di RSUD Kota Semarang. Universitas Gadjah Mada Yogyakarta

8. Larasati I, Susilo H, Riyadi. Analisis Sistem Informasi Manajemen Persediaan Obat. J Adm Bisnis. 2013;1(2):57-67.

9. M. P. Mokodompit, N. Nurlaela. 2017. Evaluasi Keamanan Sistem Informasi Akademik Menggunakan (Studi Kasus Pada Peguruan Tinggi X). J. Sist. Inf. Bisnis. vol. 6 , no. 2 .

10. Sidiq M., 2018. Penerapan Sistem Informasi Manajemen di Rumah Sakit Putri Hijau Medan. Jurnal Ilmiah Kesehatan, Vol. 17 no.02. Medan, Sumatera Utara.
11. Karim A. 2017. Sistem Informasi Pengolahan Data Kriminal Pada Kepolisian. Media Cetak, Vol. 2.

12. Irawan D., 2014. Sistem Informasi Manajemen Rumah Sakit Harapan Bunda.

13. Abdullah, M. (2014). Manajemen dan evaluasi kinerja karyawan Yogyakarta : Aswaja Pressido.

14. Radliya R., dkk. 2015. Audit Sistem Informasi Manajemen Pada RSUD Kota Tasikmalaya. Universitas Komputer Indonesia.

15. Putri E. N., dkk. 2015. Pengaruh Motivasi Kerja dan Kemampuan Kerja Terhadap Komitmen Organisasional dan Kinerja Pegawai. JISIP: Jurnal Ilmu Sosial dan Ilmu Politik. Vol. 4, No. 1.

16. Rahayu S., 2018. Pengaruh Karakteristik Individu dan Implementasi Budaya Keselamatan Pasien Terhadap Insiden Keselamatan Pasien di Rumah Sakit Umum Daerah Banten. Jurnal Manajemen dan Administrasi Rumah Sakit Vol. 2, No. 2. Universitas Respati Indonesia.

17. Saputra E., Misfariyan. 2014. Analisis Penerimaan Sistem Informasi Manajemen Rumah Sakit Umum Daerah Bangkinang Menggunakan Metode Technology Acceptance Model (TAM). Jurusan Sistem Informasi Fakultas Sains dan Teknologi Universitas Islam Negeri Sultan Syarif Kasim. Riau.

18. Putra H. S. D, Siswanto M. 2016. Pengaruh Kualitas Sistem, Kualitas Informasi dan Kualitas Layanan Terhadap Kepuasan Pengguna Sistem Informasi Manajemen Rumah Sakit Daerah Kalisat Kabupaten Jember. Seminar Hasil Penelitian dan Pengabdian Masyarakat Dana BOPTN.

19. Herpian. 2019. Sistem Informasi Manajemen Rumah Sakit Umum Dewi Sartika Kotapinang Berbasis Web. Jurnal Infotek, Vol 4, No 3, Hal .9-17.

20. Zulkarnaen, D. R., Wahyudi, R., \& Wijanarko, A. 2017. Audit Sistem Informasi Pada Rumah Sakit Umum Daerah Banyumas Menggunakan Framework Cobit 4. Probisnis, 10(2), 27-37.

21. Mustofa, A., \& Handani, S. W. 2017. Pengukuran Kinerja Sistem Informasi Tata Kelola Keuangan Kantor Kecamatan Kemranjen Kabupaten Banyumas Menggunakan Framework Cobit 5.0 Pada Domain Mea (Monitor, Evaluate, and Assess). Pro Bisnis, 10(2). 
22. Novita S., dkk. 2014. Sistem Informasi Manajemen Rumah Sakit Harapan Bunda Pringsewu Lampung. Jurnal TAM (Technology Acceptance Model). Volume 2. Lampung.

23. Karim, A., \& Purba, E. (2018). Sistem Informasi Pendataan Penduduk Kelurahan Kampung Mesjid Berbasis Web. Sistem Informasi Pendataan Penduduk Kelurahan Kampung Mesjid Berbasis Web, 537-545.

24. Rukmiyati, N. M. S., \& Budiartha, I. K. 2016. Pengaruh Kualitas Sistem Informasi, Kualitas Informasi Dan Perceived Usefulness Pada Kepuasan Pengguna Akhir Software Akuntansi (Studi Empiris Pada Hotel Berbintang Di Provinsi Bali). EJurnal Ekonomi Dan Bisnis Universitas Udayana $5.1,1,115-142$.

25. Widodo, A., Putranti, H. R. D., \& Nurchayati. 2016. Pengaruh Kualitas Sistem Aplikasi dan Kualitas Informasi Terhadap Kepuasan Pengguna Sistem Aplikasi RTS (Rail Ticketing System). Jurmal Media Ekonomi Dan Manajemen, 31(2), 160-181.

26. Putro, S. W., Semuel, P. D. H., Ritzky, K., \& Brahmana, SE., M. 2014. Pengaruh kualitas layanan dan kualitas produk terhadap kepuasan pelanggan dan loyalitas konsumen restoran happy garden surabaya. Manajemen Pemasaran, 2(1), 1-9.

27. Noviyanty. 2016. Mengukur Kesuksesan Sistem Akuntansi Instansi Basis Akrual (SAIBA) Menggunakan Model DeLone \& McLean. Jurnal Tata Kelola \& Akuntabilitas Keuangan Negara. Vol. 02, No. 02, Hal 151-173.

28. K.S Purwanto dan Pawirosumarto S., 2017. Pengaruh Kualitas Sistem, Kualitas Informasi, dan Kualitas Layanan Terhadap Penggunaan Sistem E-learning di Program
Pascasarjana Universitas Mercu Buana. Jurnal Manajemen. Volume XXI, No. 02, halaman 282-305.

29. S. Sakkinah and S. Patmanthara, 2017. "Analisis keberhasilan sistem e-learning smk negeri 1 malang," Elinvo. Electronics, Informatics, Vocat. Educ., vol. 2, no. 1, pp. 59-63,

30. W. H. DeLone and E. R. McLean, "Information systems success: The quest for the dependent variable," Inf. Syst. Res., vol. 3, no. 1, pp. 60-95, 1992.3.

31. T. Sutabri. 2012. Konsep Dasar Informasi. Yogyakarta: Andi Offset.

32. Kadir. 2014 Pengenalan Sistem Informasi. Yogyakarta: Andi Yogyakarta,

33. DeLone, W. H., McLean, E. R. 2003. The DeLone and McLean Model of Information Systems Success : A Ten-Year Update. J. Manag. Inf. Syst. Vol. 19(4): 9-30.

34. Julyanti, dkk. 2017. Evaluasi Penyimpanan dan Pendistribusian Obat di Instalasi Farmasi Rumah Sakit Siloam Manado. Pharmacon (Jurnal Ilmiah Farmasi). Vol. 6 No. 4. Manado.

35. Qiyaam, N., Furqoni, N., \& Hariati. 2016. Evaluasi Manajemen Penyimpanan Obat di Gudang Obat Instalasi Farmasi Rumah Sakit Umum Daerah dr. R. Soedjono Selong Lombok Timur. Jurnal Ilmiah Ibnu Sina, 1(1), 61-70.

How to cite this article: Zai Y, Ginting CN, Nasution SW et.al. Evaluation of the use of information systems pharmacy management officer pharmacy in RSU Royal Prima Medan year 2020. International Journal of Research and Review. 2021; 8(10): 511-519. DOI: https://doi.org/10.52403/ijrr.20211065 